GA-A16668

\title{
MASTER
}

\section{COMPATIBILITY OF ALUMINIDE-COATED HASTELLOY X AND INCONEL 617 IN A SIMULATED GAS-COOLED REACTOR ENVIRONMENT}

\author{
by \\ J. CHIN, W. R. JOHNSON, and K. CHEN
}

$\mathrm{GA}-\mathrm{A}--16668$

DE82 013307

MARCH 1982 


\section{DISCLAIMER}

This report was prepared as an account of work sponsored by an agency of the United States Government. Neither the United States Government nor any agency Thereof, nor any of their employees, makes any warranty, express or implied, or assumes any legal liability or responsibility for the accuracy, completeness, or usefulness of any information, apparatus, product, or process disclosed, or represents that its use would not infringe privately owned rights. Reference herein to any specific commercial product, process, or service by trade name, trademark, manufacturer, or otherwise does not necessarily constitute or imply its endorsement, recommendation, or favoring by the United States Government or any agency thereof. The views and opinions of authors expressed herein do not necessarily state or reflect those of the United States Government or any agency thereof. 


\section{DISCLAIMER}

Portions of this document may be illegible in electronic image products. Images are produced from the best available original document. 


\section{DISCLAIMER}

This report was prepared as an account of work sponsored by an agency of the United States Government. Neither the United States Government nor any agency thereof, nor any of their employees, makes any warranty, express or implied, or assumes any legal liability or responsibility for the accuracy, completeness, or usefulness of any information, apparatus, product, or process disclosed, or represents that its use would not infringe privately owned rights. Reference herein to any specific commercial product, process, or service by trade name, trademark, manufacturer, or other-

wise, does not necessarily constitute or imply its endorsement, recommendation, or favoring by the United States Government or any agency thereof. The views and opinions of authors expressed herein do not necessarily state or reflect those of the United States Government or any agency thereof. 
GA-A16668

\title{
COMPATIBILITY OF ALUMINIDE-COATED HASTELLOY X AND INCONEL 617 IN A SIMULATED GAS-COOLED REACTOR ENVIRONMENT
}

\author{
by \\ J. CHIN, W. R. JOHNSON, and K. CHEN*
}

This is a preprint of a paper to be presented at the Interna tional Conference on Metallurgical Coatings and Process Technology, April 49, 1982, San Diego, California, and to be published in the Proceedings.

\section{Work supported by Contract DE-AT03-76ET35301 for the San Francisco Operations Office Department of Energy}

* General Dynamics Corporation, San Diego, CA

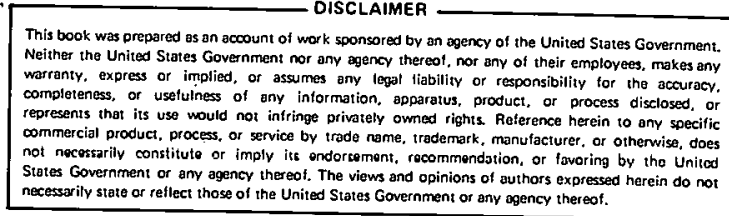
GENERAL ATOMIC PROJECT 7400 MARCH 1982 


\section{THIS PAGE ,}

\section{WAS INTENTIONALLY}

LEFT BI.ANK

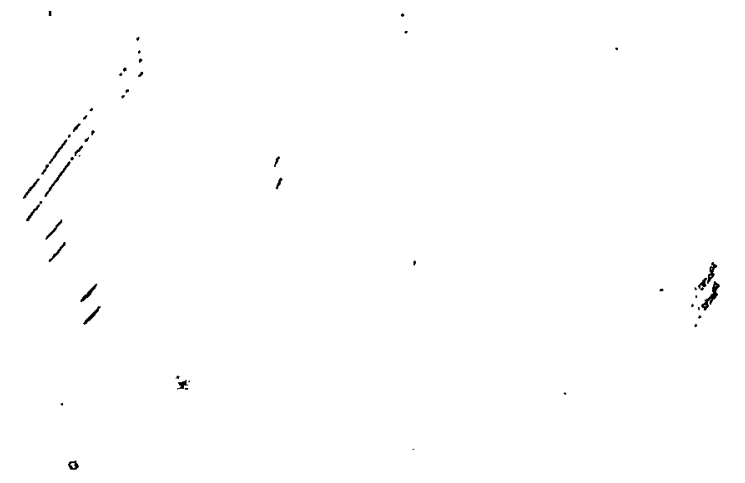




\begin{abstract}
Commercially prepared aluminide coatings on Hastelloy $\mathrm{X}$ and Inconel 617 substrates were exposed to controlled-impurity helium at $850^{\circ}$ and $950^{\circ} \mathrm{C}$ for $3000 \mathrm{~h}$. Optical and scanning electron (SEM) microscopy, electron microprobe profiles, and SEM X-ray mapping were used to evaluate and compare exposed and unexposed control samples. Four coatings were evaluated: aluminide, aluminide with platinum, aluminide with chromium, and aluminide with rhodium. With extended time at elevated temperature, nickel diffused into the aluminide coatings to form $\varepsilon$-phase (NijAl). This diffusion was the primary cause of porosity formation at the aluminide/alloy interface. Aluminide coatings with chromium (HI-15) showed the lowest coating/substrate interface porosity and intermetallic phase growth. The presence of excess chromium in the HI-15 aluminide-coated Hastelloy $X$ sample is believed to have partially compensated for the nickel 1088 by its diffusion into the nickel-depleted coating substrate transition zone. None of the other coating additions had an obvious effect on the overall behavior of aluminide-coated Hastelloy $X$ or Incone 1617 in the impure belium environment. The exterior of the aluminide coatings was not visually affected by the impure helium. Carbide precipitation below the coating/substrate interface, resulting from carbon ingress from the helium environment, was observed in uncoated control samples. Carburization of aluminide-coated substrates was less extensive than that of uncoated materials and was related to the degree of porosity at the coating/alloy interface.
\end{abstract}




\section{INTRODUCTION}

A primary coolant system which will operate above $800^{\circ} \mathrm{C}$ is critical for the use of gas-cooled high-temperature reactors (HTGRs) in high-temperature process heat applications in the $1990 \mathrm{~s}$ and beyond. The development of such a system is dependent on materials which are compatible with impure helium at temperatures above $800^{\circ} \mathrm{C}$. Helium with trace impurities of $\mathrm{B}_{2}, \mathrm{CO}, \mathrm{CH}_{4}$, and $\mathrm{H}_{2} \mathrm{O}$ is a strong carburizing medium for austenitic alloys above $800^{\circ} \mathrm{C}$ (Refs. 1-4). This medium is both carburizing and oxidizing, and carburization is the dominant cause of property degradation in the metal alloys used for HTGR structures.

This paper summarizes an examination of commercially applied aluminide coatings on Hastelloy $X$ and Incone 1617 exposed to controlled-impurity helium at $850^{\circ}$ and $950^{\circ} \mathrm{C}$. The alloys selected for examination, Hastelloy $X$ and Inconel 617, are two of the most promising commercially available alloys for HTGR component applications because of their excellent high-temperature strength and fabricability. Bowever, they both suffer carburization in simulated BTGR helium at $>650^{\circ} \mathrm{C}$, which limits their high-temperature usefulness (Ref. 5). Thus, these alloys need improvements in the form of additives, coatings, or claddings to survive HTGR target operating temperatures. The goal of this study was to determine if the comercial coatings typically used to improve the oxidation resistance of nickel-base alloys could also. be effective in improving carburization resistance.

Two types of corrosion barrier coatings were selected for evaluation: (1) aluminide and (2) aluminide plus metal. These coatings have been extensively used to improve the oxidation resistance of nickel-base alloys for high-temperature turbine engine parts. Pack-cementation aluminide and aluminide coatings with chromium, platinum, or rhodium additions were investigated. Fitzer et ale (Ref. 6), Pichoir (Ref. 7), and Goward at ale (Refs. 8. 9) show that the effectiveness of aluminide coatings on nickel-base 
alloys is dependent on the composition of the substrate and the coatings. It is also dependent on the processing temperatures used to apply the coating 8 .

In general, the details of the process conditions for applying comercial coatings are proprietary. Therefore, information about these conditions, which determine part of the activity of the elements of the coating8, is not available. However, knowing the chemical composition of the as-applied coated samples and monitoring the changes in chemical composition across the coating/subatrate interface as a function of time enable the stability of the elements in this transition region to be qualitatively inferred. 


\section{EXPERIMENTAL PROCEDORES}

The aluminide-coated Hastelloy $X$ and Inconel 617 test samples were supplied by commercial vendors as follows:

1. RT-21, aluminide coatings by Chromalloy Research and Technology Division, Orangeburg, New York.

2. RT-22, aluminide coatings with platinum by Chromalloy Research and Technology Division, Orangeburg. New York.

3. BB coatings, aluminide coatings with rhodium by Chromizing Company, Gardena, California.

4. HI-15, aluminide coatings with chromium by Alloy Surfaces Company. Wilmington. Delaware.

Table 1 gives the chemical compositions of the substrate alloys. Disk and rod sample geometries were used: the disks were $2.54 \mathrm{~cm}$ in diameter and $0.3 \mathrm{~cm}$ thick; the rod samples were $0.635 \mathrm{~cm}$ in diameter and $2.54 \mathrm{~cm}$ long. All samples were surface finlshed to 16 rims or better prior to coating application. Aluminide coatings approximately 30- to 63- $\mu \mathrm{m}$ thick were applied to all surfaces.

The test samples were mounted in alumina holders (Fig. 1), and the holder was mounted in the alumina furnace retort of a once-through, controlled-impurity, hellum corrosion test system. This system, shown in Fig. 2, includes a dew point hygrometer "for determining $\mathrm{H}_{2} \mathrm{O}$ concentration and a gas chromatograph for determining $\mathrm{H}_{2}, \mathrm{CO}, \mathrm{CH}_{4}$, and $\mathrm{CO}_{2}$ concentrations. In this system, nuclear-grade helium is further purified by passing it through a $5 \mathrm{~A}$ molecular sieve and activated charcoal at liquid-nitrogen temperature $\left(-196^{\circ} \mathrm{C}\right)$. Controlled quantities of research-purity $\mathrm{B}_{2}, \mathrm{CB}_{4}$, and 
TABLE 1

CHEMICAL COYPOSITION OF SUBSTRATE MATERIALS

\begin{tabular}{|c|c|c|c|c|c|c|c|c|c|c|c|c|c|c|}
\hline \multirow[b]{2}{*}{ Material } & \multirow{2}{*}{$\begin{array}{c}\text { Heat } \\
\text { Number }\end{array}$} & \multicolumn{12}{|c|}{ Chemical Composition (wt $\%$ )(a) } & \multirow{2}{*}{$\begin{array}{r}\text { Vendor } \\
\text { Coat ing } \\
\text { Number }\end{array}$} \\
\hline & & c & $\mathrm{Fe}$ & $\mathrm{Ni}$ & $\mathbf{C r}$ & Co & Mo & Al & Mn & si & $\mathbf{P}$ & B & W & \\
\hline \multirow[t]{2}{*}{ Hastelloy $\mathrm{X}$} & C16258 & 0.061 & 19.84 & 46.08 & 21.26 & 2.11 & 9.02 & -- & 0.73 & 0.005 & 0.015 & 0.0034 & 0.31 & $\mathrm{R} \dot{\mathrm{T}}-21, \mathrm{RT}-22, \mathrm{BB}, \mathrm{BI}-15$ \\
\hline & 260074774 & 0.09 & 19.69 & 45.55 & 21.84 & 2.43 & 8.47 & -- & 0.70 & 0.59 & 0.016 & 0.003 & 0.64 & \\
\hline Inconel 617 & X00A9US & 0.07 & 0.22 & 54.90 & 21.99 & 12.53 & 9.06 & 0.98 & 0.07 & 0.15 . & -- & -- & -- & HI - 15, RT-21 \\
\hline
\end{tabular}

(a) Vendor snalysis. 


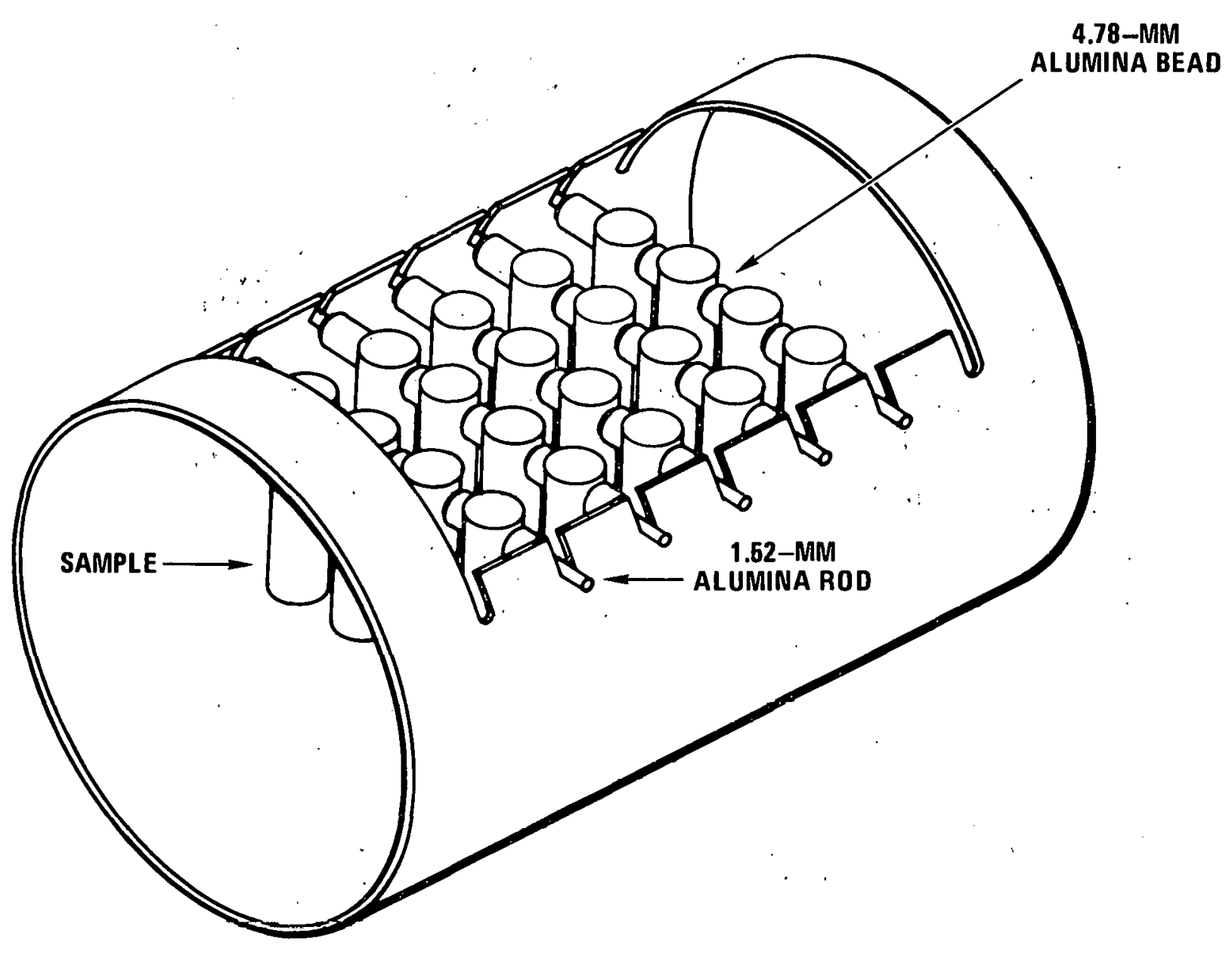

Fig. 1. Schematic diagram of alumina sample holder 


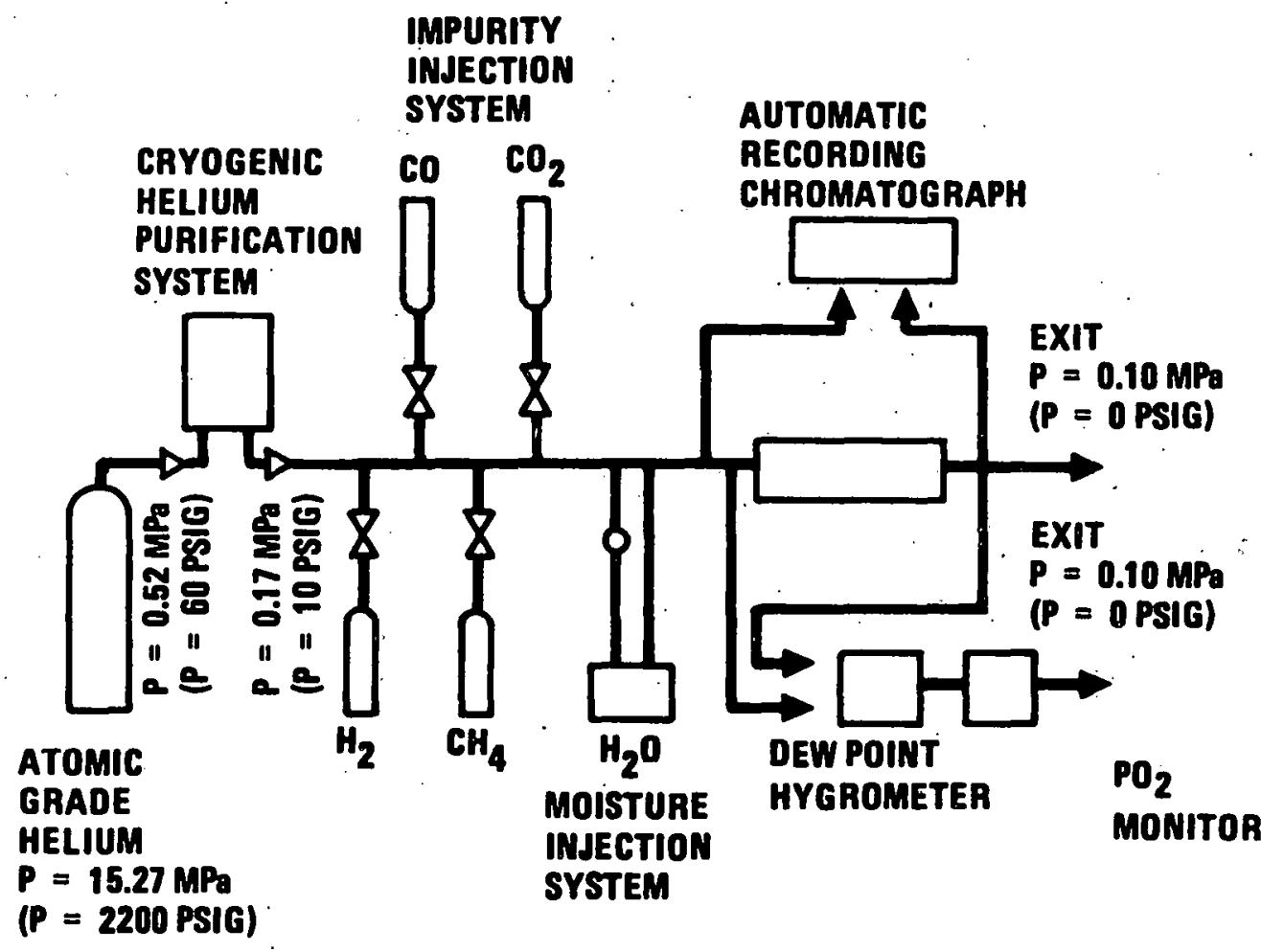

Fig. 2. Schematic diagram of General Atomic once-through controlled-impurity helium corrosion test system 
CO are added through micrometering valves in a mixing manifold, and the mixture is supplied to the aging furnace retort at $1000 \mathrm{~cm}^{3} / \mathrm{min}$ and a pressure of $0.165 \mathrm{MPa}$. The furnaces for the corrosion tests were of the threezone, resistance-heated, horizontal-tube type with a 70-mm-i.d., 910-mm-1ong alumina retort. The average residence time of a gas molecule in the retort was about 3 min.

Samples were exposed to helium containing $50 \mathrm{~Pa} \mathrm{H},<0.05 \mathrm{~Pa} \mathrm{H} \mathrm{H}_{2}, 5 \mathrm{~Pa}$ CO, and $5 \mathrm{~Pa} \mathrm{CH} 4$ at $850^{\circ}$ and $950^{\circ} \mathrm{C}$; the samples were removed at 1000 and $3000 \mathrm{~h}$. To normalize the comparisons of the aluminide coatings, the $3000-\mathrm{h}$ test data are compared with those for the as-received control specimens. 


\section{RESULTS AND CONCLUSIONS}

Helium-exposed, coated and control (uncoated) samples were sectioned for metallurgical evaluation, and metallographic mounts were prepared and used for scanning electron microscope (SEM), electron microprobe, and meta1lographic examination. Most samples were electroplated with nickel prior to mounting to define the compositional variations in the coating surface more clearly.

POROSITY

Two distinct features were characteristic of all the aluminide-coated Hastelloy $X$ or Inconel 617 samples tested: the development of (1) discrete transition layers between the coating and the substrate and (2) porosity in the first transition layer between the coating and the substrate. The thickness of the transition layer and the rate at which it and the porosity developed were different for each coating/substrate combination. The thickness of the transition layer was also different at the two exposure temperatures.

Figures 3 and 4 are photomicrographs of aluminide HI-15 (chromium addition) on Inconel 617 and aluminide RT-21 (no metal addition) on Hastelloy $X$ samples. The cross sections of the coated samples were compared with unexposed, as-received samples from the comercial coating sources. The behavior of these samples in the $3000-\mathrm{h}, 850^{\circ}$ and $950^{\circ} \mathrm{C}$ tests is considered typical of the aluminide coatings tested. The as-received aluminide HI-15 coating on Inconel 617 exhibits porosity at both the interface between the coating and the substrate and in the outer surface of the aluminide coating. During exposure, the internal porosity grew, but the exterior surface was not significantly changed. 


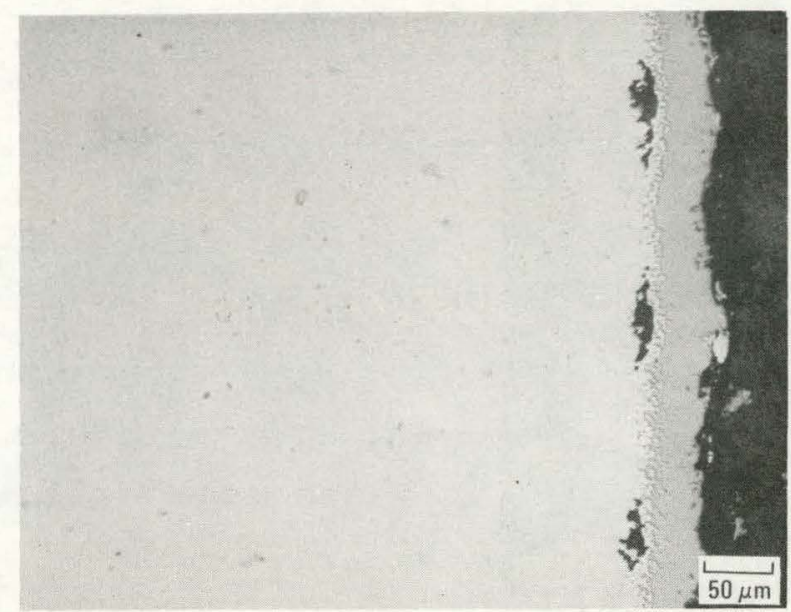

(a)

\section{AS RECEIVED}

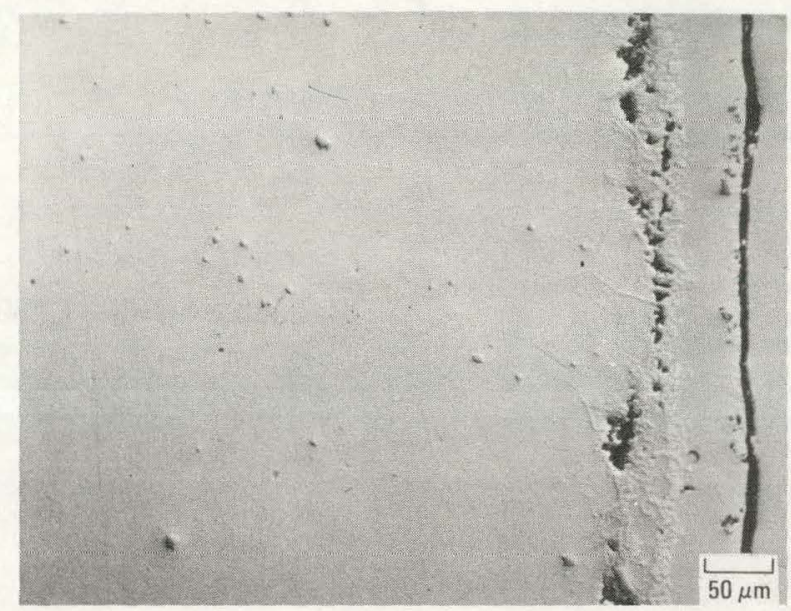

(b)

AFTER 3000 HOURS AT $850^{\circ} \mathrm{C}$

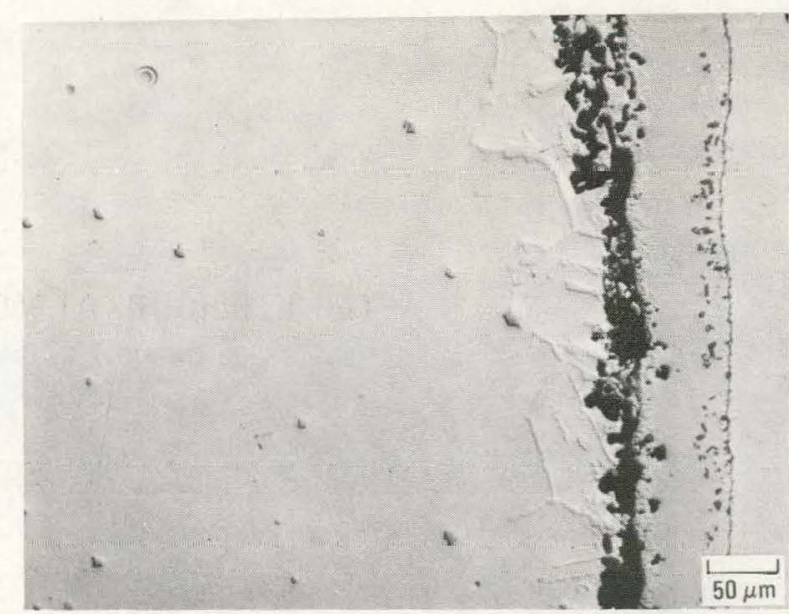

(c)

AFTER 3000 HOURS AT $950^{\circ} \mathrm{C}$

Fig. 3. Optical photomicrographs showing surface conditions and internal microstructure of HI-15 aluminide-coated Inconel 617: (a) asreceived; (b) and (c) exposed for $3000 \mathrm{~h}$ in controlled-impurity helium at $850^{\circ}$ and $950^{\circ} \mathrm{C}$ 


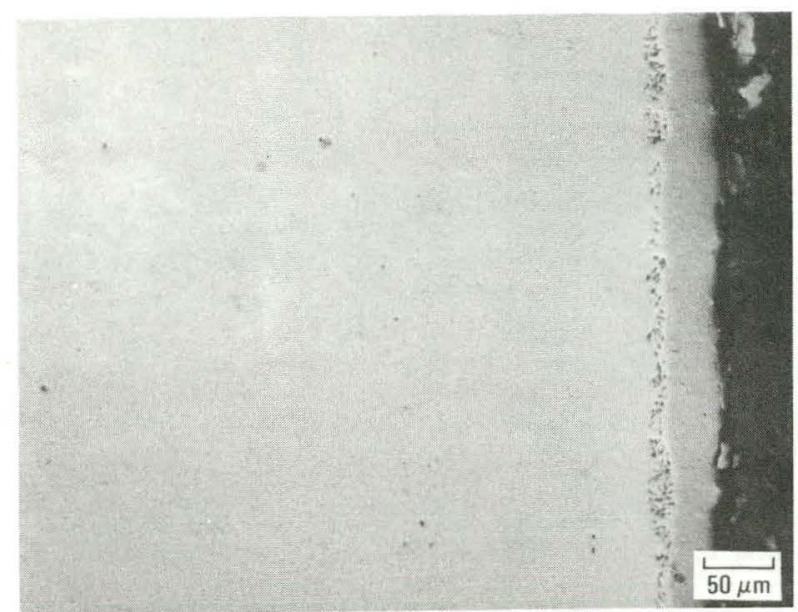

(a)

AS RECEIVED

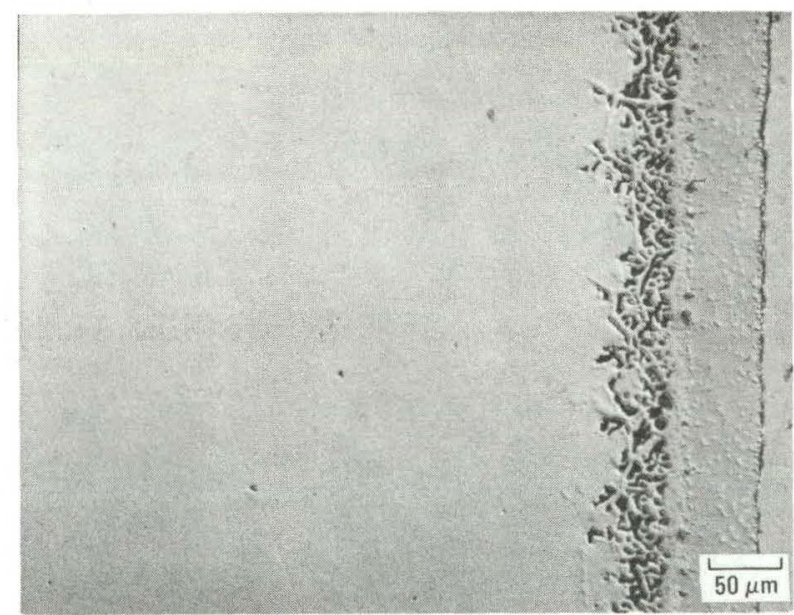

(b)

AFTER 3000 HOURS AT $850^{\circ} \mathrm{C}$

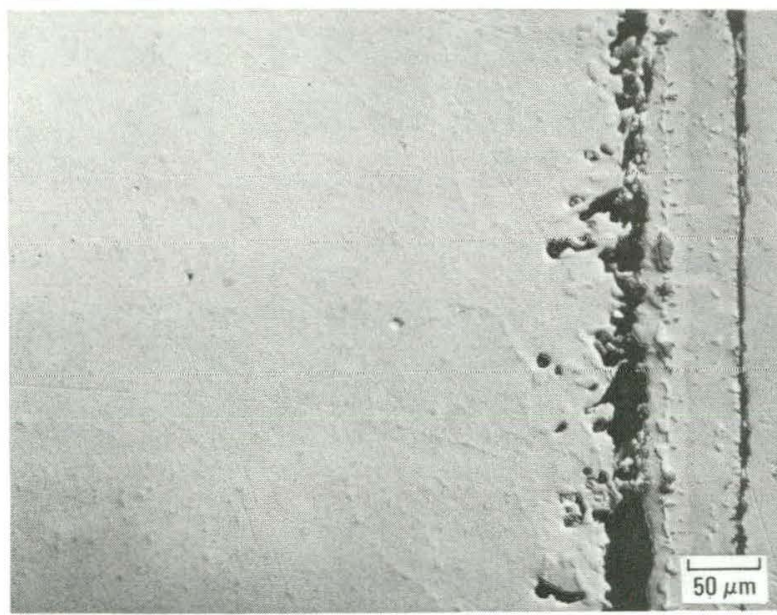

(c)

AFTER 3000 HOURS AT $950^{\circ} \mathrm{C}$

Fig. 4. Optical photomicrographs showing surface condition and internal microstructure of RT-21 aluminide-coated Hastelloy X: (a) asreceived; (b) and (c) exposed for $3000 \mathrm{~h}$ in controlled-impurity helium at $850^{\circ}$ and $950^{\circ} \mathrm{C}$ 
The exterior surface of the aluminide RT-22 coating on Hastelloy $\mathrm{X}$ also showed no visual changes after the $850^{\circ}$ and $950^{\circ} \mathrm{C}$ exposures. The porosity in this as-received sample was finely divided and uniformily distributed. With time at temperature, this porosity and an intermetallic phase diffusion zone between the aluminide and alloy surfaces grew like roots into the substrate surface. Once the porosity interconnected and a nearly continuous gap developed between the coating and the substrate, finger growth porosity into the substrate ceased.

Figure 5 summarizes the coating/substrate interface porosity observed in the samples as a percent of the interface surface area. The figure shows that the lowest porosity developed in the HI-15-coated Hastelloy X sample. This sample had significantly less porosity than the same coating on Inconel 617. The added chromium content of the HI-15 coating apparently helped reduce the porosity of the sample compared with the RT-21-coated Hastelloy $X$ sample which contained less chromium in the coating. The addition of platinum to the coating, sample RT-22/Hastelloy $\mathrm{X}$, also produced less porosity than the aluminide coatings without additives, but the reduction was not as large as that observed for the chromium-doped HI-15 coating. Rhodium had no apparent influence on the porosity formed at the coating/substrate interface.

The amount of porosity as well as the total thickness of the porosity/intermetallic phase diffusion zone (Fig. 6) increased in the $950^{\circ} \mathrm{C}$ aged samples compared with the $850^{\circ} \mathrm{C}$ aged samples. This indicates that the porosity is the result of a Kirkendall differential diffusion process rather than trapped gas bubbles. The lack of generated pores at other than the coating/substrate interface indicates that the porosity does not originate from decreased solubility of gases in the substrate or coating. The lower rate of growth of the transition zone of the HI-15/Hastelloy $\mathrm{X}$ combination shows that the chemical composition of this system slows the development of Kirkendall void formation. 


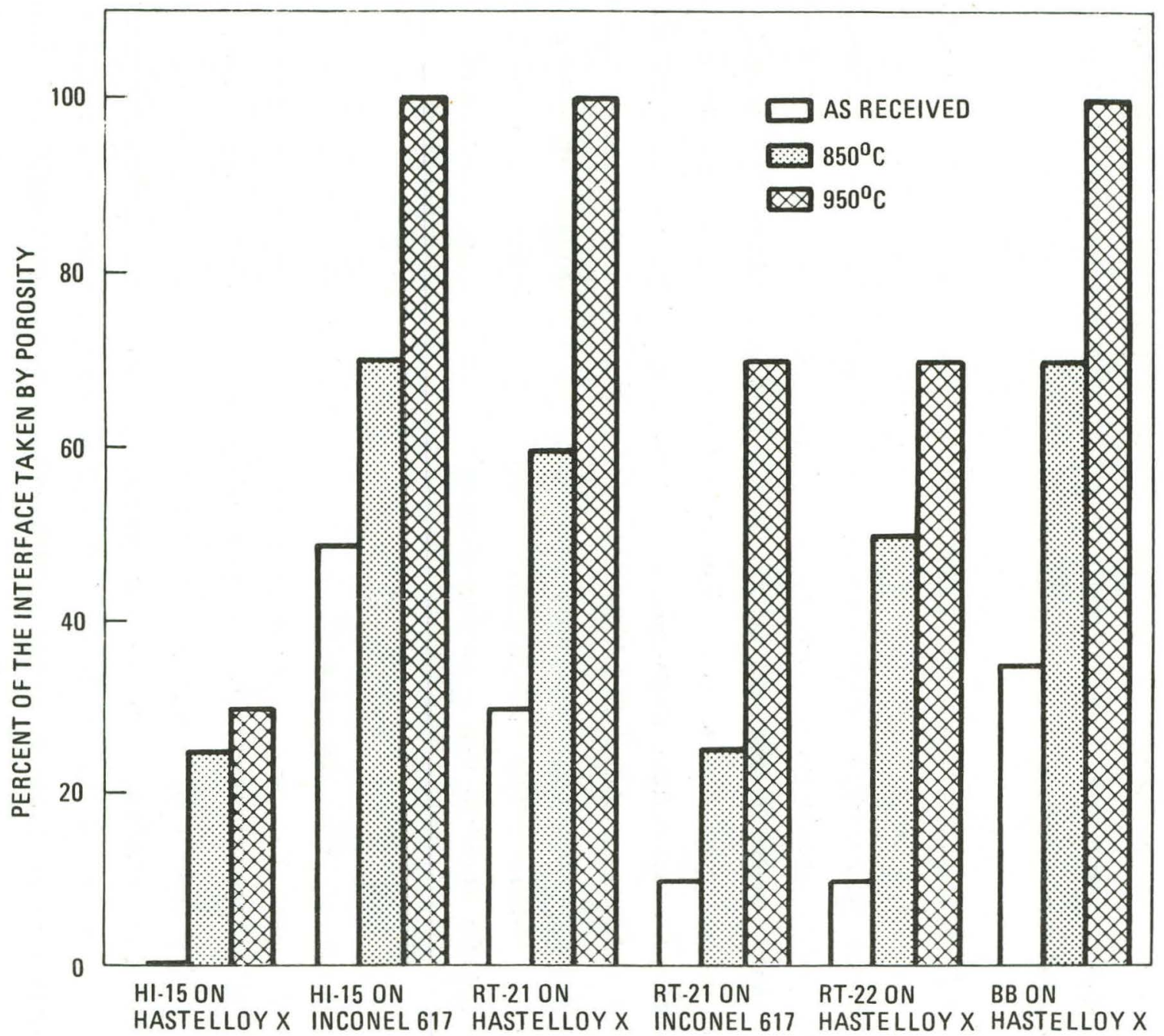

Fig. 5. Coating/substrate interface porosity fraction (\%) for aluminide-coated Hastelloy $X$ and Inconel 617, as-received and after 3000-h exposure in controlled-impurity helium at $850^{\circ}$ and $950^{\circ} \mathrm{C}$ 


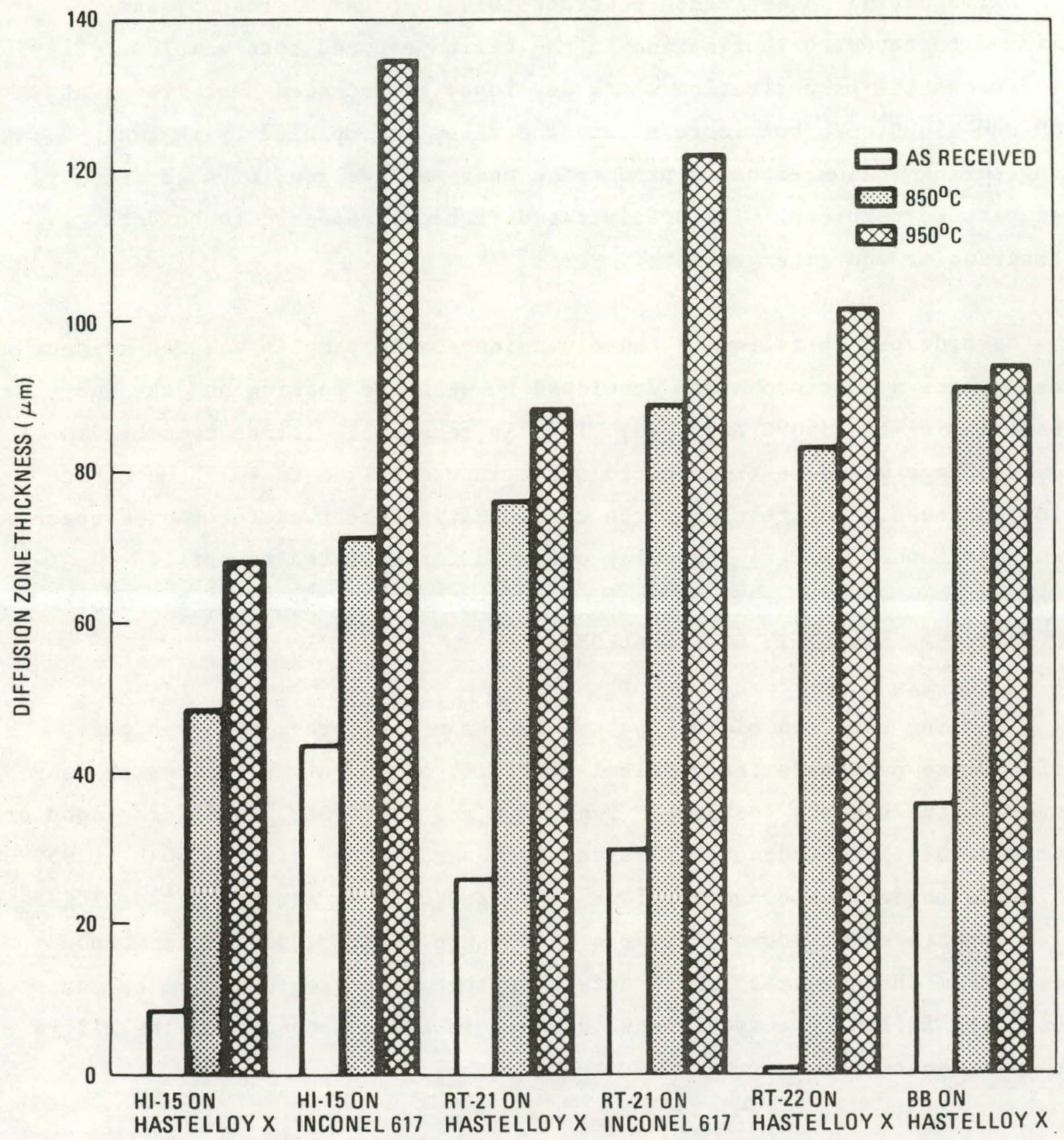

Fig. 6. Maximum diffusion zone thickness for aluminide-coated Hastelloy X and Inconel 617, as-received and after 3000-h exposure in controlled-impurity helium at $850^{\circ}$ and $950^{\circ} \mathrm{C}$ 


\section{CARBURIZATION}

Differential interference contrast (DIC) optical microscopy was utilized to detect carburization in the helium-exposed test samples. Figure 7 shows the carburization which developed in uncoated Hastelloy $\mathrm{X}$ at $850^{\circ}$ and $950^{\circ} \mathrm{C}$. Carbon ingress into the alloy accompanied by thermal aging during helium exposure produced a near-surface zone of high-density. precipitated carbides. The precipitated carbides appeared to be both intragranular and intergranular.

Carbide precipitation in the aluminide-coated samples was not evident except where a continuous gap developed between the coating and the substrate during the $950^{\circ} \mathrm{C}$ exposure. This is reasonable, since breaches in such coatings would be expected to allow impure helium to reach uncoated alloy surfaces. Nevertheless, the carburization observed for coated specimens was generally less than that observed for uncoated material.

COMPOSITIONAL STABILITY OF THE ALLOYS

Scanning electron microscope and electron microprobe analyses were performed to determine the chemical stability of the nickel alloys in contact with the various coatings. Figures 8 and 9 are SEM photomicrographs of aluminide $\mathrm{HI}-15$ on Inconel 617 as-received samples and after $3000 \mathrm{~h}$ at $950^{\circ} \mathrm{C}$ in impure helium. The compositions of selected areas across the coating/ alloy interface are shown. Figures 10 through 12 are typical microprobe traces from these tests. These data show that exposure to impure helium caused the following compositional changes in the components of the alloys and their coatings:

1. Aluminum. With time at temperature, the aluminum-rich aluminide layer at the coating exterior broadens. Because there is no aluminum resevoir to maintain the as-deposited concentration of aluminum, the overall aluminum concentration of this layer decreases. Aluminum diffusion into the alloy substrate occurs but is apparently sluggish. 


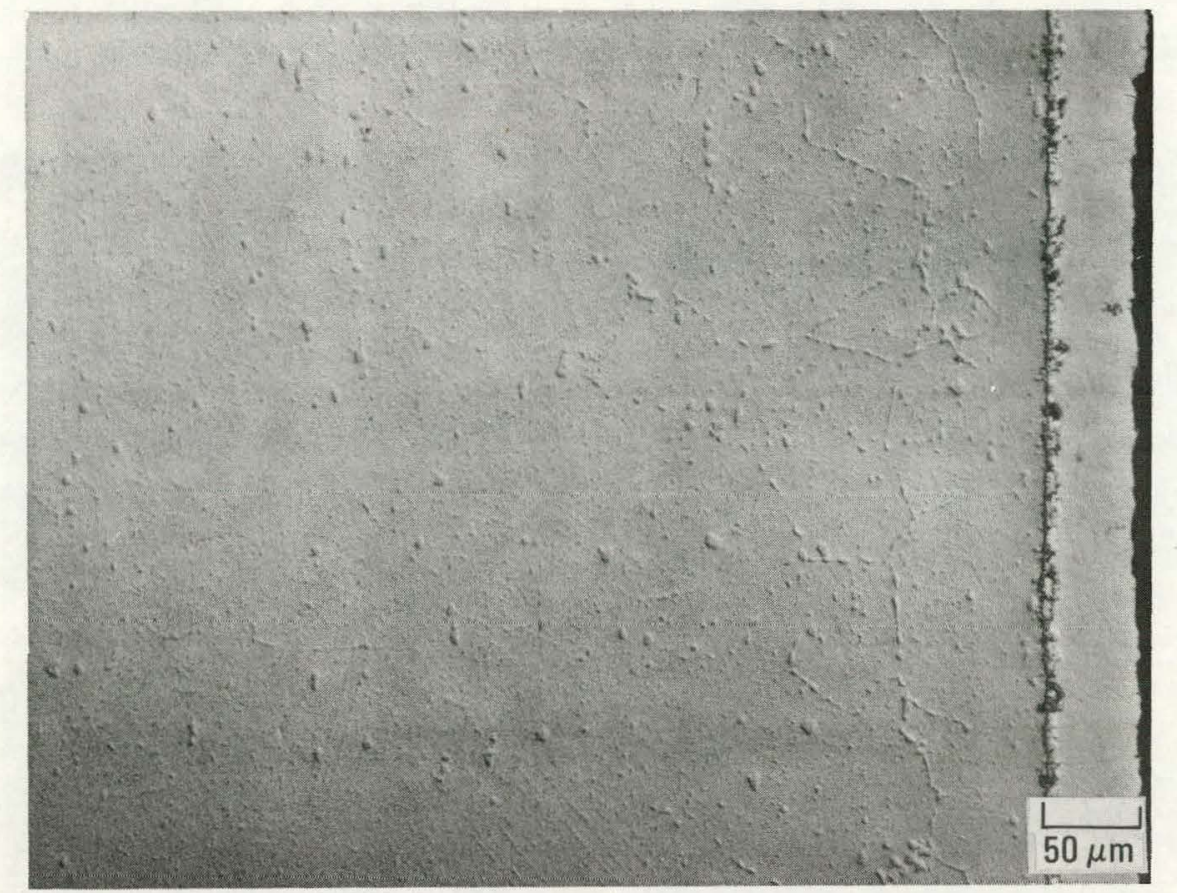

(a)

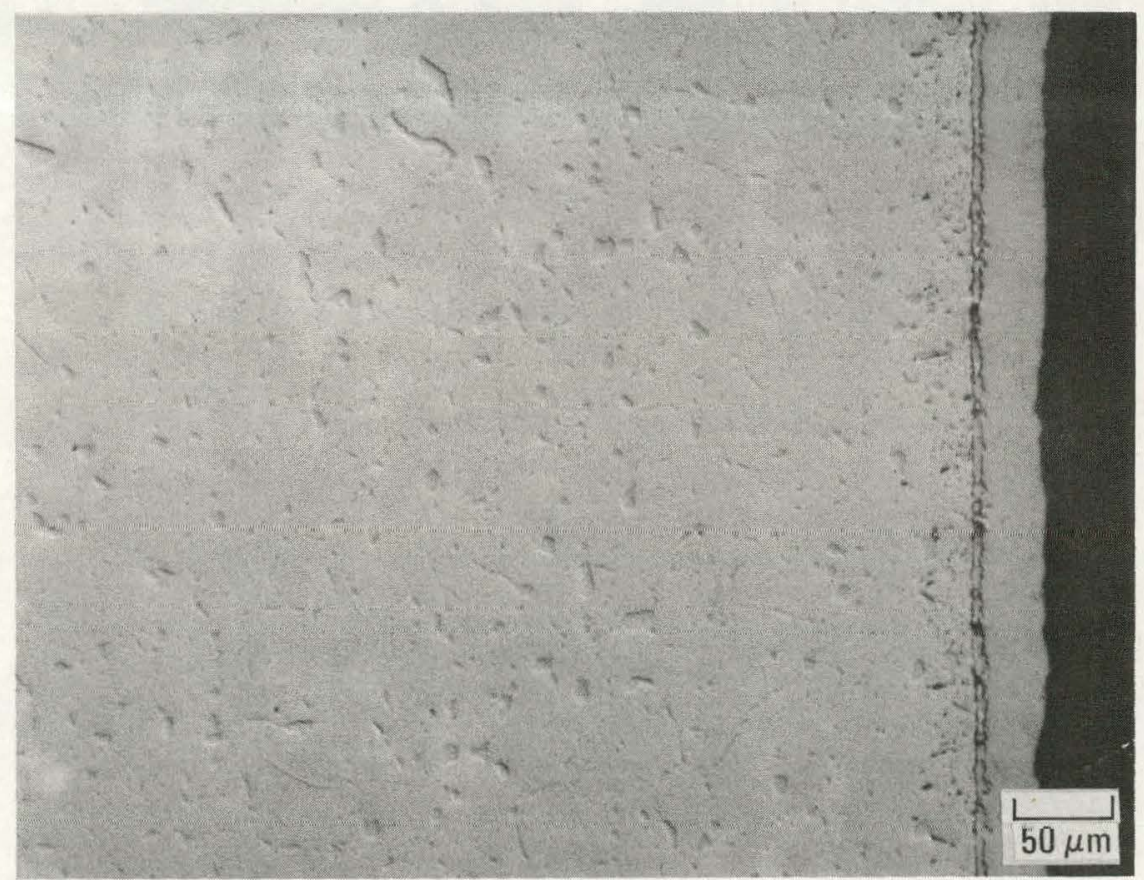

(b)

Fig. 7. Optical photomicrographs showing surface and internal microstructure of uncoated Hastelloy $\mathrm{X}$ after $3000-\mathrm{h}$ exposure in controlled-impurity helium at (a) $850^{\circ} \mathrm{C}$ and (b) $950^{\circ} \mathrm{C}$; microstructures show increased carbide precipitation (carburization) near surface: white layer above surface scale is electroplated nickel 


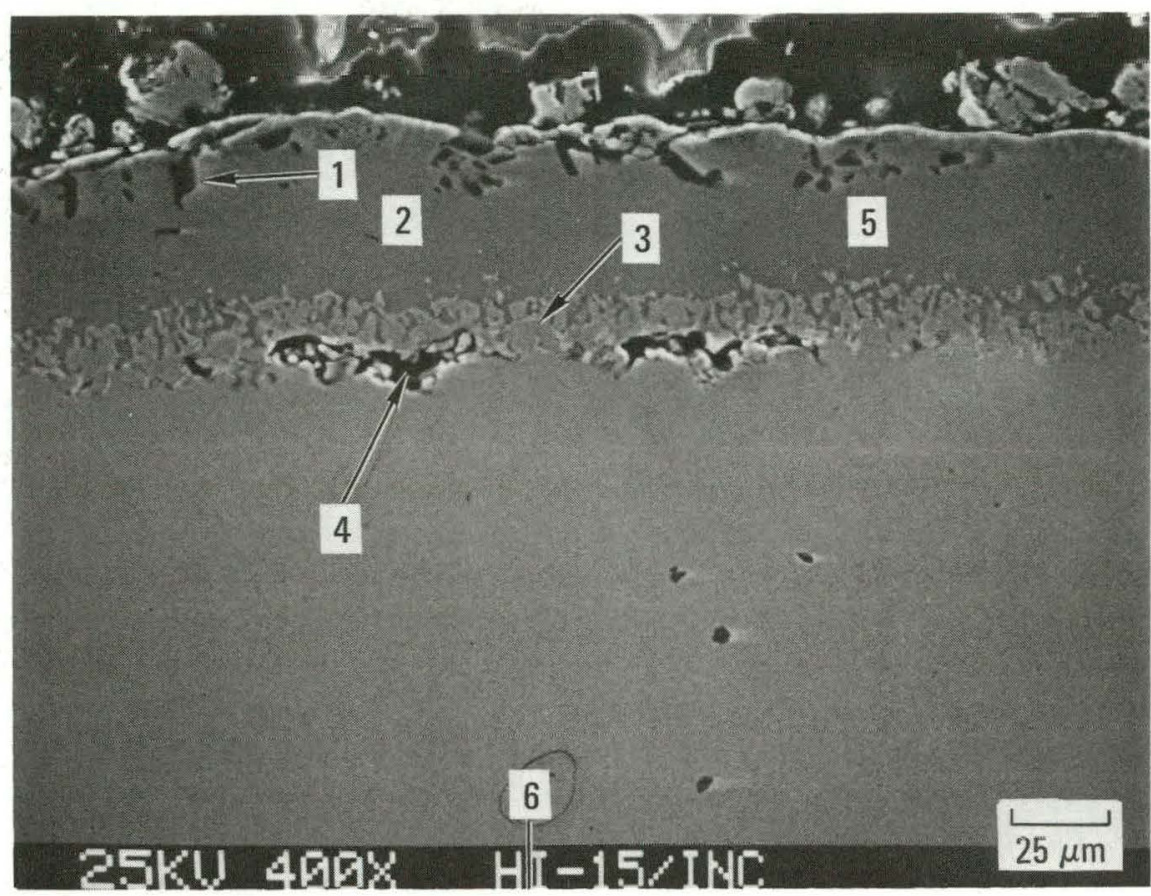

1

2

3

94.837\%AL $\quad 44.637 \% \mathrm{AL} \quad 10.404 \% \mathrm{AL}$

$0.337 \% \mathrm{SI} \quad 0.450 \% \mathrm{SI} \quad 0.472 \% \mathrm{SI}$

$0.014 \% \mathrm{MO} \quad 0.059 \% \mathrm{MO} \quad 8.191 \% \mathrm{MO}$

$0.000 \% \mathrm{TI} \quad 0.033 \% \mathrm{TI} \quad 0.231 \% \mathrm{TI}$

$0.632 \% \mathrm{CR} \quad 1.646 \% \mathrm{CR} \quad 19.742 \% \mathrm{CR}$

$0.000 \% \mathrm{FE} \quad 0.049 \% \mathrm{FE} \quad 0.180 \% \mathrm{FE}$

$0.314 \% \mathrm{CO} \quad 7.200 \% \mathrm{CO} \quad 15.458 \% \mathrm{CO}$

$3.863 \% \mathrm{NI} \quad 45.923 \% \mathrm{NI} \quad 45.318 \% \mathrm{NI}$

4

5

6

$17.538 \% \mathrm{AL} \quad 43.964 \% \mathrm{AL} \quad 1.429 \% \mathrm{AL}$

$50.871 \% \mathrm{SI} \quad 0.767 \% \mathrm{SI} \quad 0.155 \% \mathrm{SI}$

$5.405 \% \mathrm{MO} \quad 0.000 \% \mathrm{MO} \quad 8.644 \% \mathrm{MO}$

$0.000 \% \mathrm{TI} \quad 0.026 \% \mathrm{TI} \quad 0.470 \% \mathrm{TI}$

$10.557 \% \mathrm{CR} \quad 1.610 \% \mathrm{CR} \quad 23.329 \% \mathrm{CR}$

$0.053 \% \mathrm{FE} \quad 0.044 \% \mathrm{FE} \quad 0.184 \% \mathrm{FE}$

$3.703 \% \mathrm{CO} \quad 7.655 \% \mathrm{CO} \quad 12.479 \% \mathrm{CO}$

$11.870 \% \mathrm{NI} \quad 45.932 \% \mathrm{NI} \quad 53.307 \% \mathrm{NI}$

Fig. 8. SEM photomicrograph showing surface microstructure and selectedarea elemental analysis (EDX) of as-received HI-15 aluminide-coated Incone1 617 


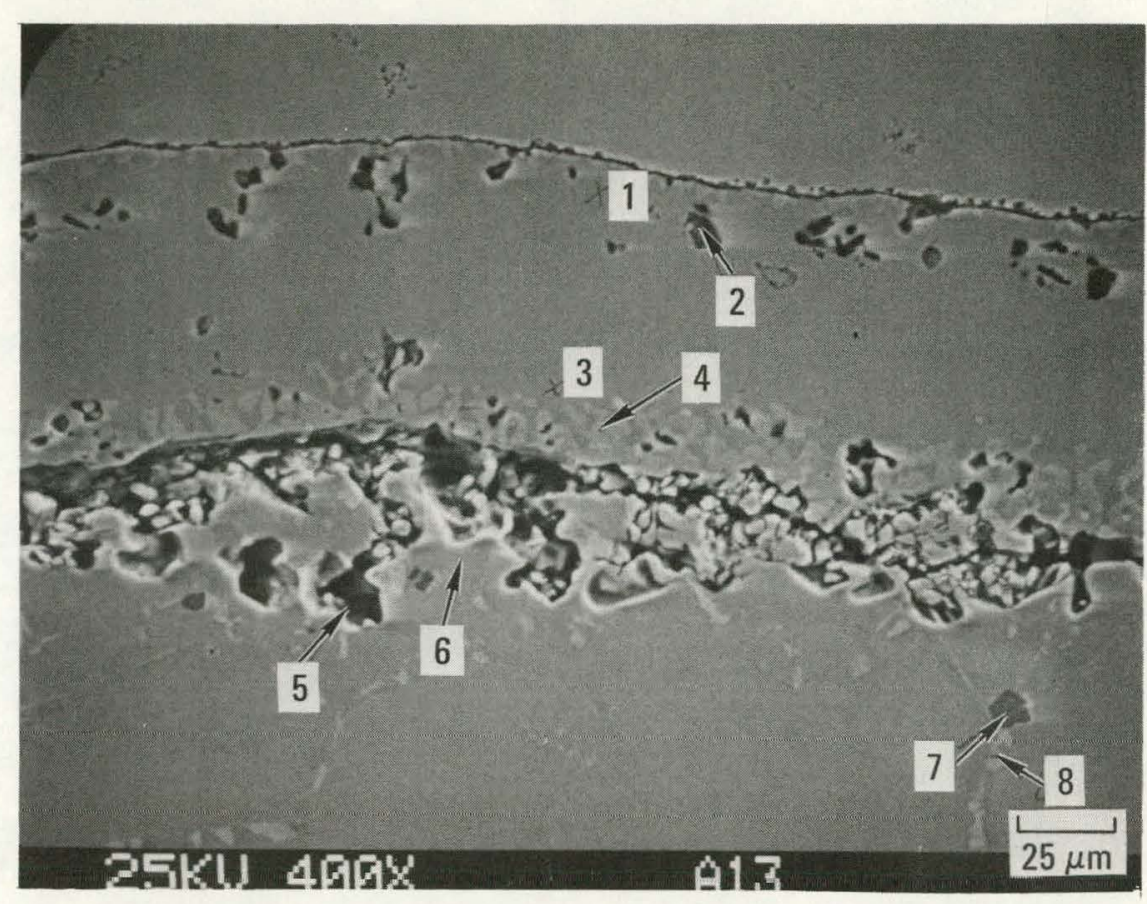

9

1

2

3

4

27. $275 \%$ AL $0.293 \%$ SI

$0.206 \% \mathrm{MO}$ $2.396 \%$ CR $0.000 \% \mathrm{FE}$

$9.958 \% \mathrm{CO}$

$59.869 \% \mathrm{NI}$ $0.000 \% \mathrm{~W}$

5

$0.952 \% \mathrm{AL}$ $0.542 \% \mathrm{SI}$

$6.493 \% \mathrm{MO}$

$43.036 \%$ CR

$1.758 \% \mathrm{FE}$

$6.976 \%$ CO

$40.240 \% \mathrm{NI}$

$0.000 \% \mathrm{~W}$

$97.040 \% \mathrm{AL}$ $0.074 \% \mathrm{SI}$

$0.127 \%$ MO

$26.798 \%$ AL $0.343 \% \mathrm{SI}$

$0.076 \%$ CR $0.000 \% \mathrm{MO}$

$2.860 \% \mathrm{CR}$

$0.099 \% \mathrm{FE}$

$0.490 \% \mathrm{CO}$

$2.089 \% \mathrm{NI}$

$0.000 \% \mathrm{~W}$

$0.000 \% \mathrm{FE}$

$9.632 \% \mathrm{CO}$

$60.365 \% \mathrm{NI}$

$0.000 \% \mathrm{~W}$

6

7

20.656 \% AL

$0.049 \% \mathrm{AL}$

$0.000 \% \mathrm{SI}$

$0.107 \% \mathrm{SI}$

$4.744 \% \mathrm{MO}$

$88.097 \% \mathrm{TI}$

$3.668 \% \mathrm{CR}$

$0.000 \% \mathrm{FE}$

$0.611 \%$ CO

$2.828 \% \mathrm{NI}$

$0.000 \% \mathrm{AL}$

$0.070 \% \mathrm{SI}$

$20.028 \%$ MO

$73.519 \%$ CR

$0.056 \% \mathrm{FE}$

$3.008 \% \mathrm{CO}$

$3.315 \% \mathrm{NI}$

$0.000 \% \mathrm{~W}$

$11.681 \%$ CR

$0.025 \% \mathrm{FE}$

$58.131 \% \mathrm{NI}$

$0.000 \% \mathrm{~W}$

\section{8}

$0.442 \% \mathrm{AL}$

$0.794 \%$ SI

$28.104 \% M O$

$0.241 \% \mathrm{TI}$

58.979 \% CR

$0.032 \% \mathrm{FE}$

$3.416 \% \mathrm{CO}$

$7.988 \% \mathrm{NI}$

\section{9}

$0.897 \% \mathrm{AL}$

$0.193 \%$ SI

$7.040 \% \mathrm{MO}$

$0.257 \% \mathrm{TI}$

$23.380 \%$ CR

$0.131 \% \mathrm{FE}$

$12.837 \%$ CO

55.261 \% N

Fig. 9. SEM photomicrograph showing surface microstructure and selectedarea elemental analysis (EDX) of HI-15 aluminide-coated Inconel 617 after $3000-\mathrm{h}$ exposure in controlled-impurity helium at $950^{\circ} \mathrm{C}$ 


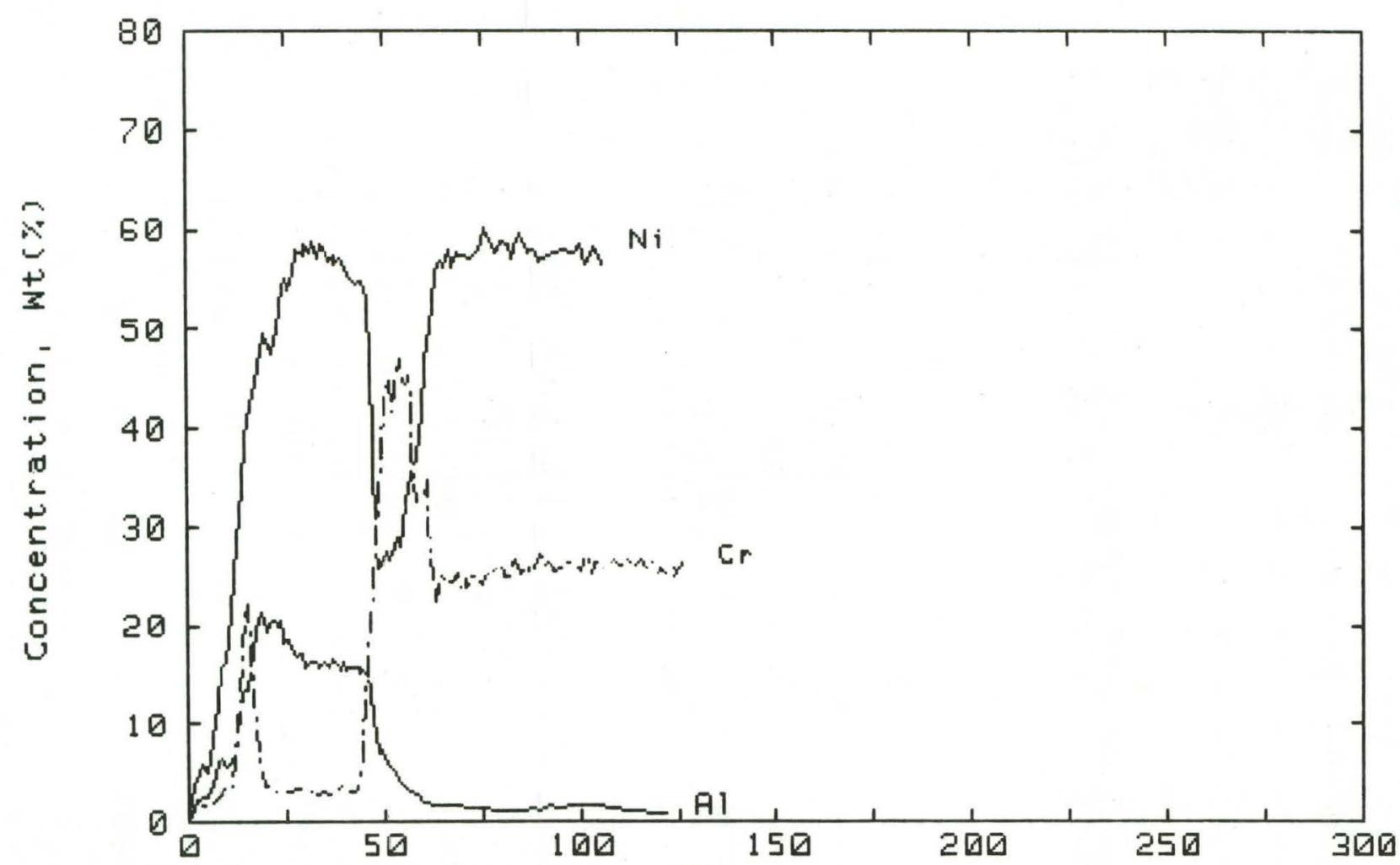

Fig. 10. Electron microprobe trace analysis across coating/substrates for as-received aluminide HI-15-coated Inconel 617 


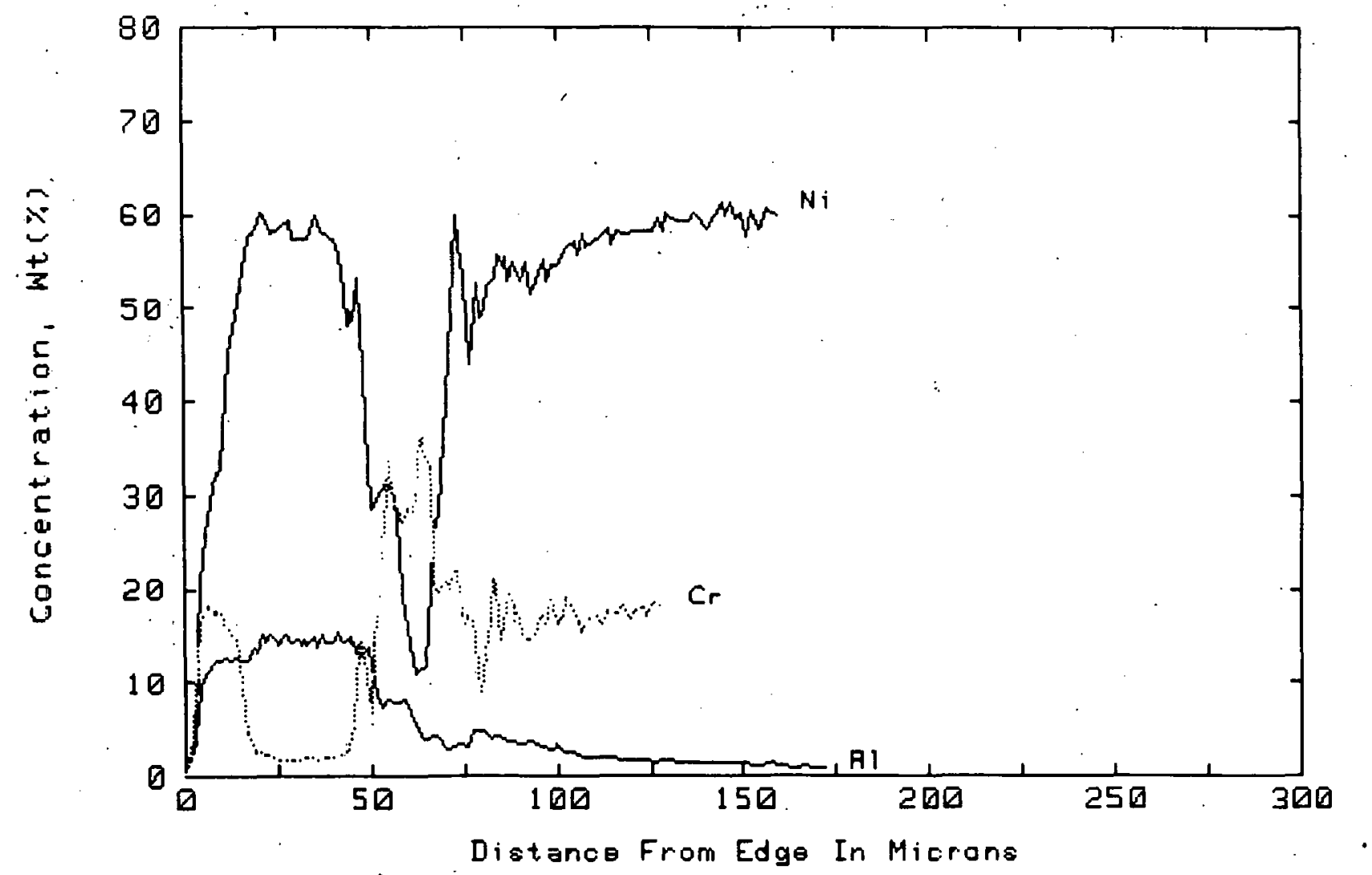

Fig. 11. Electron microprobe trace analysis across coating/substrates for aluminide HI-15-coated Incone 1617 after $3000 \mathrm{~h}$ at $850 \mathrm{oc}$ in impure helium 


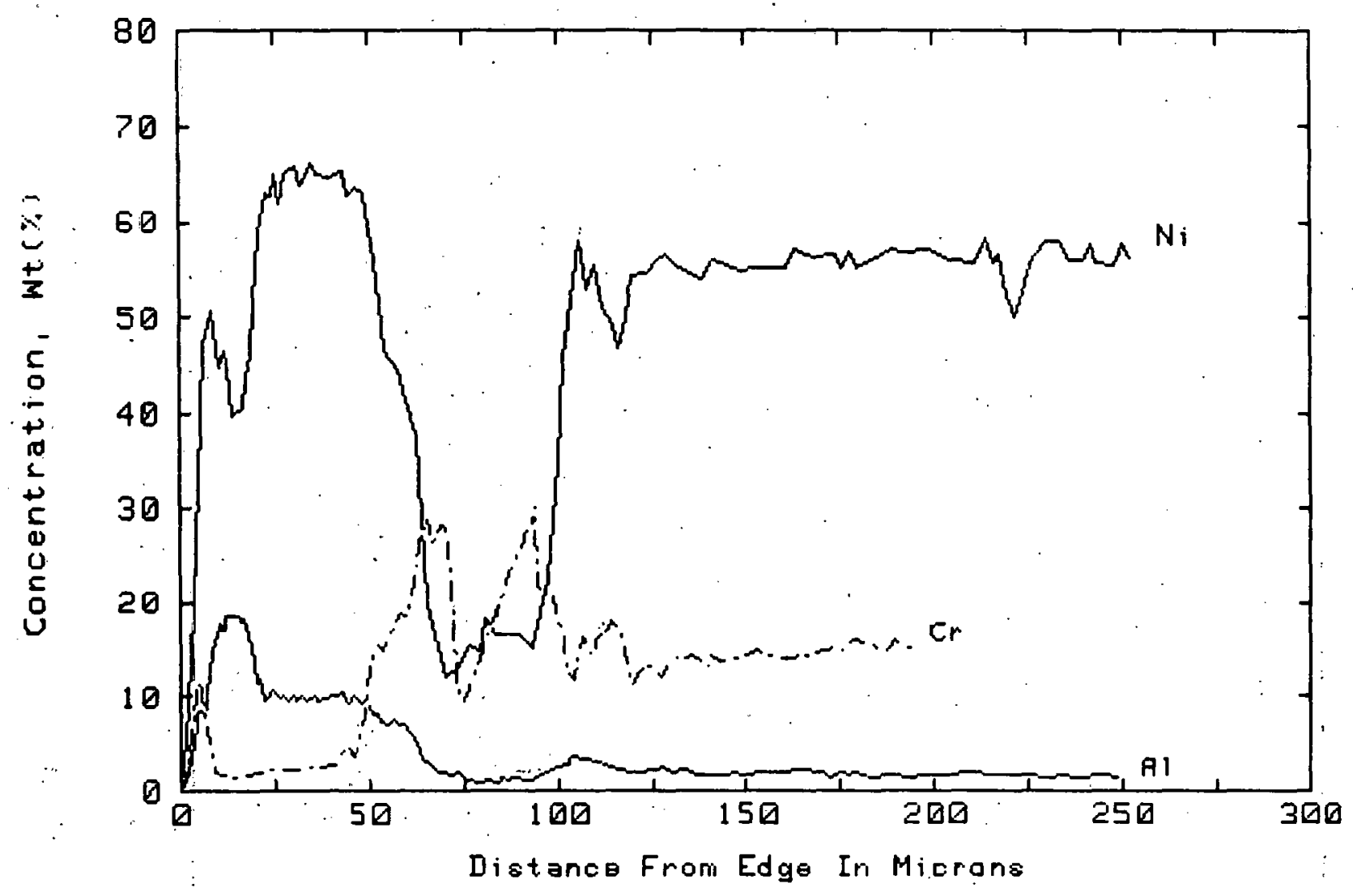

Fig. 12. Electron microprobe trace analysis across coating/substrates for aluminide HI-15-coated Inconel 6.17 after $3000 \mathrm{~h}$ at $950^{\circ} \mathrm{C}$ in impure helium 
2. Nickel. Nickel diffuses from the substrate into the aluminide coating. This agrees with the observations of Pichoir (Ref. 7), Hickl (Ref, 10), Goward (Ref. 9), and others, who showed that a $\gamma$-phase ( $\mathrm{Ni}_{2} \mathrm{Al}_{3}$ ) layer initially forms during the aluminizing process and is gradually displaced by an $\varepsilon$-phase ( $\left.N i_{3} A 1\right)$. This also accounts for the observed broadening of the aluminum-rich zone and the apparent uniformity of the lowered aluminum content. The observed composition of 65 wt \% nickel and $10 \mathrm{wt} \%$ aluminum corresponds almost exactly to the $\mathrm{Ni} \mathrm{H}_{\mathrm{Al}}$ composition of this layer. Next to this outer layer there is a nickel depletion zone from which the nickel forming the Ni3Al layer originates. This depleted layer forms the voids in the transition zone between the alloy substrate and the aluminide coating. The creation of Rirkendall voids in the transition zone which are parallel to the direction of nickel diffusion is reasonable if one considers the lower activation energy required for surface diffusion rather than lattice diffusion.

3. Chromium. Chromium enriches the interface between the alloy and the coatings; it also enriches the coating surface. The chromium content of the NijAl phase was almost constant at approximately 3 wt $\%$. In the chromium-rich HI-15 aluminide coating on Hastelloy $X$, the chromium replaced nickel in the nickel-depleted transition zone, which apparently inhibited void formation. This may account for the lower porosity and transition zone thickness observed in this sample. Less chromium was measured in the as-received, HI-15 aluminide coating on Inconel 617, which would account for the more pronounced porosity growth in this coating/substrate combination.

4. Iron. Iron shows little apparent diffusion into or away from the aluminide coatings. For this reason, iron profiles are only shown in a few of the microprobe summaries. There is no indication that iron influences the behavior of these coated alloys in impure helium at either $850^{\circ}$ or $950^{\circ} \mathrm{C}$. 
5. Platinum and rhodium. There are no significant differences in the behavior in impure helium of aluminide coat ings with or without platinum or rhodium on Hastelloy $X$ and Inconel 617: Rhodium from the coating does diffuse into Hastelloy $\bar{x}$ a $950^{\circ} \mathrm{C}$; but there is nothing to suggest that this element is beneficial.

6. Molybdenum. Molybdenum enrichment occurs at the coating/substrate interface in the as-received aluminide-coated alloys. The molybdenum does not significantly migrate into the coating during the impure helium $850^{\circ}$ and $950^{\circ} \mathrm{C}$ exposures. Molybdenum becomes prominent in Hastelloy $X$ grain boundaries during these tests but is otherwise uniform. Molybdenum was not prominent in the grain boundaries of exposed Inconel 617 . 


\section{SUMMARY}

Hastelloy $X$ and Inconel 617 substrates were coated with comercially prepared aluminide coating, including aluminide with platinum, chromium, or rhodium additions. These samples were examined after 1000 and $3000 \mathrm{~h}$ of exposure in helium containing controlled amounts of $\mathrm{H}_{2}, \mathrm{CH}_{4}$, and $\mathrm{CO}$. The results of the $3000-\mathrm{h}$ tests are summarized as follows:

1. Nickel diffusion from both Hastelloy $X$ and Inconel 617 into the aluminide coatings caused the formation of Kirkendall porosity between the coatings and the alloy substrates.

2. Excess chromium in the coating slowed the rate of formation of porosity and the growth of an intermetallic transition layer between the coating and the substrate.

3. All aluminide coatings appeared to suppress the carburization of the substrate alloys. The exterior surface of the aluminide coatings showed relatively little damage from the carburizing environment of the impure helium.

4. Iron and cobalt play no apparent role in the diffusion behavior of these alloy/coating combinations, even though their content in both Hastelloy $X$ and Inconel 617 is significant. 
REFERENCES

1. Weinberg, A. F., and J. M. Scoffin, Exposure of Reactor Structural Materials to Impure Helium at Elevated Temperature,“ USÁCC Report GA-2998, General Atomic Company, March, 1962.

2. Pearce, R. J., R. A. V. Huddle, and P. Rofstad, "Fundamental Aspects of the Interaction of HTR Helium With Metals and Alloys, CEGB Report DPTN/522 (modified), January 1974.

3. Mazandarany, F. N., and G. Y. Lai, Corrosion Behavior of Selected Structural Materials in a Simulated Steam-Cycle HTGR Helium Environment, DOE Report GA-A14446, General Atomic Company, October 1977.

4. Lai, G. Y., and W. R. Johnson, “Carburization of Austenitic Alloys by Gaseous Impurities in Helium, DOE Report GA-A15790; General Atomic Company, March 1980.

5. Rosenwasser, S. N.. and W. R. Johnson, “Gas-Turbine HTGR Materials Screening Test Program Interim Results, E ERDA Report GA-Al3931, General Atomic Company. June 30, 1976.

6. Fitzer, E., and H. J. Maurer, “Spontane Ausbildung von Diffusionsbarrieren in Alitierschichten auf Nickellegierungen, Arch. Bisenhuttente 49, 95-100 (1978).

7. Pichoir, R.. "Aluminide Coatings on Nickel or Cobalt Base Superalloys: Principal Parameters Determining Their Morphology and Composition, in Proceedings of the Conference on High Temperature Alloys for GasTurbine Engines. I,iege, Belgium, September 1978, pp. 191-208.

8. Goward, G. W., D. H. Boone, and C. S. Giggins, "Formation and Degradation Mechanisms of Aluminide Coatings on Nickel-Base Superalloys, "Trans. ASK 60, 228-241 (1967).

9. Goward, G. W.. and D. H. Boone, Mechanisms of Formation of Diffusion Aluminide Coatings on Nickel-Base Superalloys, " Oxidation of Metals 3 . 475-495 (1971). 
10. Hick1, A. J., and R. W. Heckel, "Kinetics of Phase Layer Growth During Aluminide Coatings of Nicke1,“ Met. Trans. A 432, 431-440 (1975). 
ACKNOWLEDGMENTS

This paper summarizes the work of the metallurgical staff of General Atomic Company. This work was supported by the Department of Energy under Contract DE-AT03-76ET35301. 